\title{
Activation and Attenuation of Transcription Factor NF-kB in Mouse Glomerular Mesangial Cells in Response to Tumor Necrosis Factor- $\alpha$, Immunoglobulin G, and Adenosine 3':5'-Cyclic Monophosphate

\author{
Evidence for Involvement of Reactive Oxygen Species
}

Joe Satriano and Detlef Schlondorff

Department of Medicine, Albert Einstein College of Medicine, Bronx, New York 10461

\begin{abstract}
The transcription factor NF-kB may play an important role in the response to tissue injury and activation of cytokines. We therefore examined the regulation of NF-kB in mesangial cells. Treatment of mesangial cells with TNF- $\alpha$ increased nuclear proteins that bound to an NF-kB-specific DNA oligonucleotide. IgG aggregates also increased nuclear NF-kB, demonstrating Fc- $\tau$ receptor-mediated activation of NF-kB. Treatment of a cytosolic preparation with the detergent deoxycholate also activated NF-kB. The binding characteristics were typical for NF-kB transcription factors as determined by competition experiments with NF-kBbinding wild type kB DNA oligonucleotides or mutated oligonucleotides. Furthermore, a monoclonal antibody against the p65 subunit of NF-kB prevented the binding of NF-kB to the $\mathrm{kB}$ oligonucleotide. To evaluate the potential role of reactive oxygen intermediates in the activation of $\mathrm{NF}-\mathrm{kB}$, we used PDTC as a scavenger and HMAP as an inhibitor of NADPH-dependent oxidase. Both PDTC and HMAP attenuated the increase in nuclear NF-kB in response to either TNF- $\alpha$ or IgG complexes. Finally, generation of superoxide anion by xanthine oxidase activated $\mathrm{NF}-\mathrm{kB}$, an effect also mitigated by PDTC. In contrast, exogenous $\mathrm{H}_{2} \mathrm{O}_{2}$ did not activate NF-kB. Preincubation of cells with 8 br-cAMP, forskolin, or $\mathrm{PGE}_{2}$ attenuated the increase in nuclear NF-kB in response to TNF- $\alpha$, aggregated IgG, or superoxide anion. Our results provide support for a role of reactive oxygen intermediates as mediators for activation of NF-kB in MC after stimulation with TNF- $\alpha$ or IgG aggregates. As an unexpected novel finding we report that cAMP can inhibit activation of NF-kB in MC. These observations may help to explain effects of TNF- $\alpha$, IgG aggregates and cAMP on generation of cytokines by mesangial cells and the resulting glomerular pathophysiology. (J. Clin. Invest. 1994. 94:16291636). Key words: chemotactic factors $\bullet$ kidney $\bullet$ gene regulation
\end{abstract}

Address correspondence to Dr. Detlef Schlondorff, Albert Einstein College of Medicine, 1300 Morris Park Ave, U-617, Bronx, New York 10461. Joe Satriano's present address is Department of Medicine, University of California San Diego, San Diego, California 92161.

Received for publication 8 December 1993 and in revised form 20 June 1994.

J. Clin. Invest.

(C) The American Society for Clinical Investigation, Inc.

0021-9738/94/10/1629/08 \$2.00

Volume 94, October 1994, 1629-1636

\section{Introduction}

Mesangial cells (MC) ${ }^{1}$ are vascular smooth muscle-derived cells that play an important role in glomerular function in the kidney (1). MC also contribute to glomerular injury by generating a number of cytokines. We recently described that TNF- $\alpha$ and IgG complexes can activate expression of the macrophage colony stimulating factor CSF-1 and monocyte chemoattractant protein MCP-1. Furthermore superoxide anion activated these genes and scavengers of free radicals attenuated these effects, implicating reactive oxygen intermediates as possible mediators of gene activation.

In eucaryotes, regulation of gene transcription can be dramatically enhanced by the binding of sequence-specific DNA binding proteins to a promoter's cis-acting element $(2,3)$. Nuclear factor $\mathrm{kB}$ (NF-kB) is a well studied pleiotropic, multisubunit transcription factor protein originally described as binding to an immunoglobulin $\mathrm{k}$ enhancer site $(\mathrm{kB})$ of $\mathrm{B}$ cells, and required for $k$ enhancer function (4). Subsequently, a wide variety of inducible genes has been shown to contain $\mathrm{kB}$ binding sites in enhancer regions (5).

$\mathrm{NF}-\mathrm{kB}$ resides in the cytoplasm of different cell types as an inactive complex of the subunits p50, p65, and an inhibitory subunit $(\mathrm{IkB})$. The $\mathrm{p} 50$ and $\mathrm{p} 65$ subunits are the best characterized members of a larger protein family (NF-kB/Rel/Dorsal). Agents that lead to immune, inflammatory, or acute phase response activate the transcription factor by release of IkB with subsequent translocation of the p50-p65 heterodimer into the nucleus. IkB can also be dissociated from NF-kB in vitro by treatment with the detergent sodium deoxycholate (DOC) (6). As activation is independent of new protein synthesis, NF-kB has been proposed to serve as an integral factor in rapidly inducing an array of genes for signaling and defense proteins $(5,7)$. Cytokines, immunoglobulins, major histocompatability antigens, and their associated proteins are among those genes responsive to NF-kB activity (8).

Phosphorylation may play an important role in the activation and metabolism of NF-kB, but the contribution of various kinases to this process remains to be defined (9-13). NF-kB also appears to be influenced by reactive oxygen intermediates (ROI). ROI are commonly produced during inflammatory pro-

1. Abbreviations used in this paper: $\mathrm{CHX}$, cycloheximide; DOC, sodium deoxycholate; Fsk, Forskolin; HMAP, 4'-hydroxy-3'-methoxy-acetophenone; IkB, inhibitory subunit of NF-kB; MC, mesangial cell; MCP, monocyte chemoattractant protein; NF-kB, nuclear factor kB; PDTC, pyrolidine dithiocarbamate; PKA, cAMP-dependent protein kinase; $\mathrm{PKC}$, protein kinase $\mathrm{C} ; \mathrm{ROI}$, reactive oxygen intermediate; $\mathrm{XO}$, xanthine oxidase-hypoxanthine. 
cesses. In mesangial cells TNF- $\alpha$ (14) and immune complexes (15) induce the production of ROI. Furthermore, MC contain an inducible, membrane bound NADPH-dependent oxidase capable of $\mathrm{H}_{2} \mathrm{O}_{2}$ and $\mathrm{O}_{2}^{-}$generation (16). Oxygen radicals, in turn, have recently been implicated as activators of NF-kB and may be a common mechanism of action for the diverse agents capable of NF-kB activation (17-20).

Macrophage colony stimulating factor (CSF-1) and monocyte chemoattractant protein (MCP-1 also known as MCAF) are two monocyte-specific inducible cytokines that contain a $\mathrm{kB}$ site upstream from their promoters $(21,22)$. CSF-1 and MCP-1 genes can be rapidly induced by a number of agents including lipopolysaccharide, PDGF, TNF- $\alpha$, IL1 , IFN- $\tau$, and occupancy of Fc receptors by aggregated IgG (22-36). We also have shown that cAMP and agents increasing cAMP generation such as forskolin and $\mathrm{PGE}_{2}$ attenuate the increase in mRNA for CSF-1 and MCP-1 in response to TNF- $\alpha$ or aggregated IgG (37). Recently we demonstrated that TNF- $\alpha$ and aggregated IgG can stimulate NADPH-dependent generation of free radicals which may serve as intracellular signals for the induction of CSF-1 and MCP-1 in glomerular mesangial cells (38). Furthermore, radical scavengers including $N$-acetyl-L-cysteine (NAC) and pyrolidine dithiocarbamate (PDTC) were able to attenuate the TNF- $\alpha$ and IgG induced expression of MCP-1 (38).

We now report activation of NF-kB by treatment of $\mathrm{MC}$ with TNF- $\alpha$ and, for the first time, with Fc- $\gamma$ receptor occupancy by aggregated IgG. 8 br-cAMP or agents which stimulate cAMP such as forskolin or $\mathrm{PGE}_{2}$ attenuate the induction of NF-kB by TNF- $\alpha$ or aggregated IgG. These results extend our previous studies on the transcriptional, mRNA, and protein levels of CSF-1 and MCP-1 in activated MC (36-38). Through the use of the NADPH oxidase inhibitor 4'-hydroxy-3'-methoxy-acetophenone (HMAP), the free radical scavenger PDTC, and the superoxide anion generating xanthine oxidase-hypoxanthine system, we provide evidence that implicate ROI generation as a common pathway for activation of NF-kB by TNF- $\alpha$ and aggregated IgG in $\mathrm{MC}$.

\section{Methods}

BSA, forskolin, $\mathrm{PGE}_{2}$, PDTC, and 8 bromo-cAMP were from Sigma Chemical Co. (St. Louis, MO). DME, penicillin $(0.66 \mathrm{mg} / \mathrm{ml})$-streptomycin $(60 \mu \mathrm{g} / \mathrm{ml})$, and FCS were purchased from Gibco BRL (Grand Island, NY). HMAP was purchased from Aldrich Chemical Co. (Milwaukee, WI). Mouse recombinant TNF- $\alpha$, acrylamide, cycloheximide ( $\mathrm{CHX}$ ), and multiprime DNA labeling systems were obtained from Boehringer Mannheim (Indianapolis, IN). $\left[\alpha{ }^{32} \mathrm{P}\right] \mathrm{dCTP}$ was purchased from New England Nuclear (Boston, MA). NF-kB p65 subunit specific monoclonal antibody was purchased from PharMingen (San Diego, $\mathrm{CA}$ ). Mouse IgG or $\mathrm{F}\left(\mathrm{ab}^{\prime}\right)_{2}$ fragment (Cappel Organon Teknika Corp., Durham, NC) was aggregated by heating to $63^{\circ} \mathrm{C}$ for $30 \mathrm{~min}$. Insoluble aggregates were removed by centrifugation at $1,000 \mathrm{rpm}$ in a microfuge for $1 \mathrm{~min}$ and the supernate served as aggregated IgG or $\mathrm{F}\left(\mathrm{ab}^{\prime}\right)_{2}$ fragments, respectively (36). All other chemicals were from Sigma Chemical Co., unless otherwise specified.

Culture of mouse MC. Mouse MC transformed with nonreplicating, noncapsid forming SV-40 virus (strain Rh 911) were kindly provided by Dr. E. Neilson, University of Pennsylvania. These cells have been previously characterized (39). In previous experiments we had established that the response to TNF $\alpha$ and aggregated IgG was comparable in the transformed MC and primary MC (38). The MC were maintained in DME medium with $1 \%$ Penicillin-Streptomycin and $2.5 \%$ FCS in an atmosphere of $95 \% \mathrm{O}_{2}, 5 \% \mathrm{CO}_{2}$. Medium was changed twice weekly. Cells were passaged weekly by harvesting with $0.25 \%$ trypsin, $1 \mathrm{mM}$ EDTA solution.

Preparation of nuclear extracts. For $16 \mathrm{~h}$ before the experiments cells were kept in medium with the omission of FCS. Incubation media, \pm experimental agents, were also without FCS. Preincubation with PDTC (0.1 mM), HMAP (100 $\mu \mathrm{g} / \mathrm{ml})$, CHX $(15 \mu \mathrm{g} / \mathrm{ml}), 8 \mathrm{br}-\mathrm{cAMP}$ $(1 \mathrm{mM})$, forskolin $\left(\mathrm{Fsk} ; 10^{-5} \mathrm{M}\right)$ or $\mathrm{PGE}_{2}\left(10^{-6} \mathrm{~m}\right)$ for $30 \mathrm{~min}$ or 1 $\mathrm{h}$ as specified. Cells were treated with TNF- $\alpha(100 \mathrm{U} / \mathrm{ml})$ or aggregated IgG $(200 \mu \mathrm{g} / \mathrm{ml}), \mathrm{XO}$ (xanthine oxidase + hypoxanthine at $10 \mathrm{mU} /$ $\mathrm{ml}$ and $0.5 \mathrm{mM}$, respectively), or hydrogen peroxide $(50 \mathrm{mM})$ for an additional $1 \mathrm{~h}$ at $37^{\circ} \mathrm{C}$.

Nuclear proteins were isolated by the method of Schriber et al. (40). In brief, confluent $\mathrm{MC}\left(5 \times 10^{6}\right.$ cells $)$ were treated with experimental agents for the times indicated, the media were then quickly aspirated and cells washed gently on ice with $10 \mathrm{ml}$ ice-cold Tris-buffered saline, pH 7.9. Cells were scraped in $1 \mathrm{ml}$ of cold hypotonic buffer A $(10 \mathrm{mM}$ Hepes, pH 7.9; $10 \mathrm{mM} \mathrm{KCl}, 0.1 \mathrm{mM}$ EDTA; $0.1 \mathrm{mM}$ EGTA; $1 \mathrm{mM}$ DTT; $0.5 \mathrm{mM}$ PMSF) $+0.6 \%$ NP-40, allowed to swell on ice for 15 min and vortexed vigorously for lysis. After a 30 -s centrifugation in a microfuge, the pellet was then washed with an additional $1 \mathrm{ml}$ cold buffer and respun. The resulting nuclear pellet was resuspended in 100 $\mu l$ ice-cold buffer $\mathrm{C}$ ( $20 \mathrm{mM}$ Hepes $\mathrm{pH} 7.9 ; 0.4 \mathrm{M} \mathrm{NaCl} ; 1 \mathrm{mM}$ EDTA; $1 \mathrm{mM}$ EGTA; $1 \mathrm{mM}$ DTT; $1 \mathrm{mM}$ PMSF) and placed in an Eppendorf thermomixer at setting 10 for $20 \mathrm{~min}$ at $4^{\circ} \mathrm{C}$. The nuclear extract was centrifuged for $10 \mathrm{~min}$ at $11,500 \mathrm{~g}$ at $4^{\circ} \mathrm{C}$; the supernatant collected, divided into aliquots and stored at $-70^{\circ} \mathrm{C}$. Protein concentration was determined by the Bio-Rad Protein Assay. $20 \mu \mathrm{g}$ of this extract, typically 1-2 $\mu \mathrm{l}$, was used for the bandshift assay.

For DOC pretreatment, cytosolic fraction $(25 \mu \mathrm{g})$ is incubated for $10 \mathrm{~min}$ at room temperature with DOC $(0.5 \% \mathrm{wt} / \mathrm{vol})$. DOC is then sequestered by addition of NP-40 (1\%) immediately before EMSA binding reaction (see EMSA in Methods).

Electrophoresis mobility shift assay (EMSA). The kB DNA sequence of the immunoglobulin gene (6) was used for the EMSA. Synthetic double stranded oligonucleotides of the following sequences were end labeled with $\left[{ }^{32} \mathrm{P}\right]$ :

$\mathrm{kB}$ :

3' GTCTCCCTGAAAGGCTCTCCC

mutated $\mathrm{kB}: \quad 5$ 'TCGACAGAATTCACTTTCCGAGAGGC

3' GTCTTAAGTGAAAGGCTCTCCGAGCT

TRE:

5'GATGCAGCTTGATGAGTCAGCCGGATCA

3' GTCGAACTACTCAGTCGGCCTAGTCTAG

The altered sequence of the mutated DNA sequence is underlined.

The DNA binding reaction was performed on ice for $20 \mathrm{~min}$ in a volume of $20 \mu \mathrm{l}$, unless otherwise specified. The reaction mixture contained $20 \mu \mathrm{g}$ of nuclear extract, $50 \mu \mathrm{g} / \mathrm{ml}$ of poly dI:dC, $10 \mathrm{mM}$ Tris pH 7.5, $100 \mathrm{mM} \mathrm{NaCl}, 1 \mathrm{mM}$ EDTA, $1 \mathrm{mM}$ DTT, $1 \mathrm{mg} / \mathrm{ml} \mathrm{BSA}, 10 \%$ glycerol and $25,000 \mathrm{cpm}\left({ }^{32} \mathrm{P}\right)$ end labeled oligonucleotide. Following incubation, the samples were loaded onto a $5 \%$ native polyacrylamide gel (acrylamide/bisacrylamide at $40: 1$ in $0.3 \times \mathrm{TBE}$ ) while running at $100 \mathrm{~V}$. After loading, the voltage was increased to $150 \mathrm{~V}$ for $2 \mathrm{~h}$. The gel was then dried and subjected to autoradiography for analysis.

For binding exclusion assays, anti-NF-kB p65 is added either before or after labeled $\mathrm{kB}$ oligonucleotide addition, as noted, for $20 \mathrm{~min}$ incubation at $37^{\circ} \mathrm{C}$.

$P K A$ induction of $N F-k B$. Nuclear protein extracts $(20 \mu \mathrm{g})$ or cytosolic fractions $(50 \mu \mathrm{g})$ were incubated in the presence or absence of 1 $\mathrm{mM} \mathrm{MgCl}, 100 \mu \mathrm{M}$ ATP or ATP gamma-S, a nonhydrolizable ATP analogue, and $0.2 \mu \mathrm{g}$ catalytic subunit of cAMP-dependent protein kinase (PKA). The DNA binding reaction, as described above in EMSA, was performed immediately after the PKA incubation.

\section{Results}

$k B$ Sequence binds NF-kB-like protein in MC. To detect $\mathrm{kB}$ binding activity in $\mathrm{MC}$, we performed electrophoretic mobility 
A

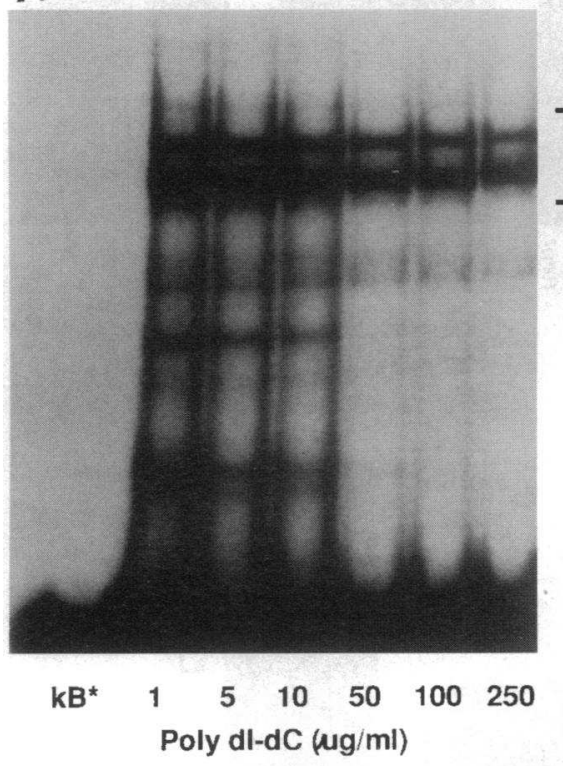

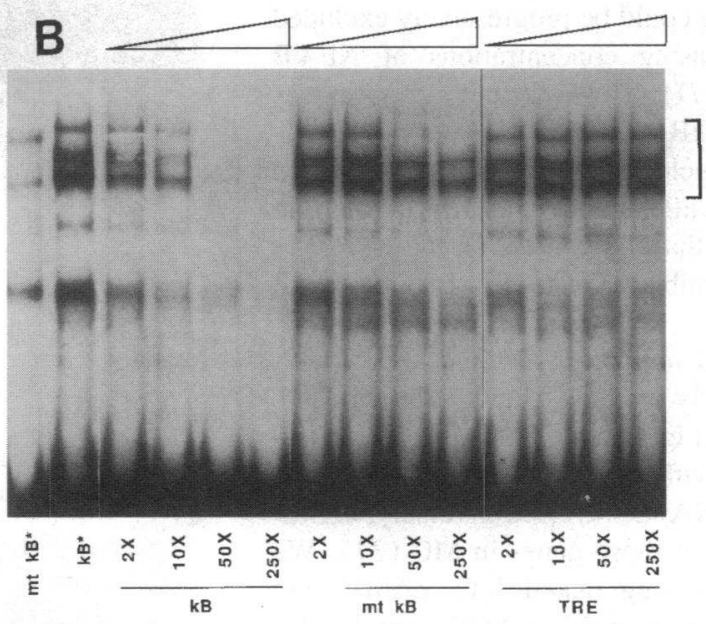

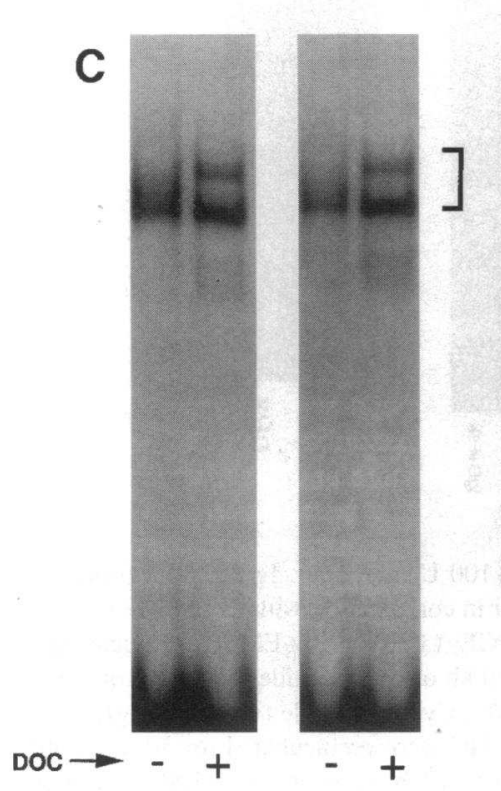

cytosolic fractions
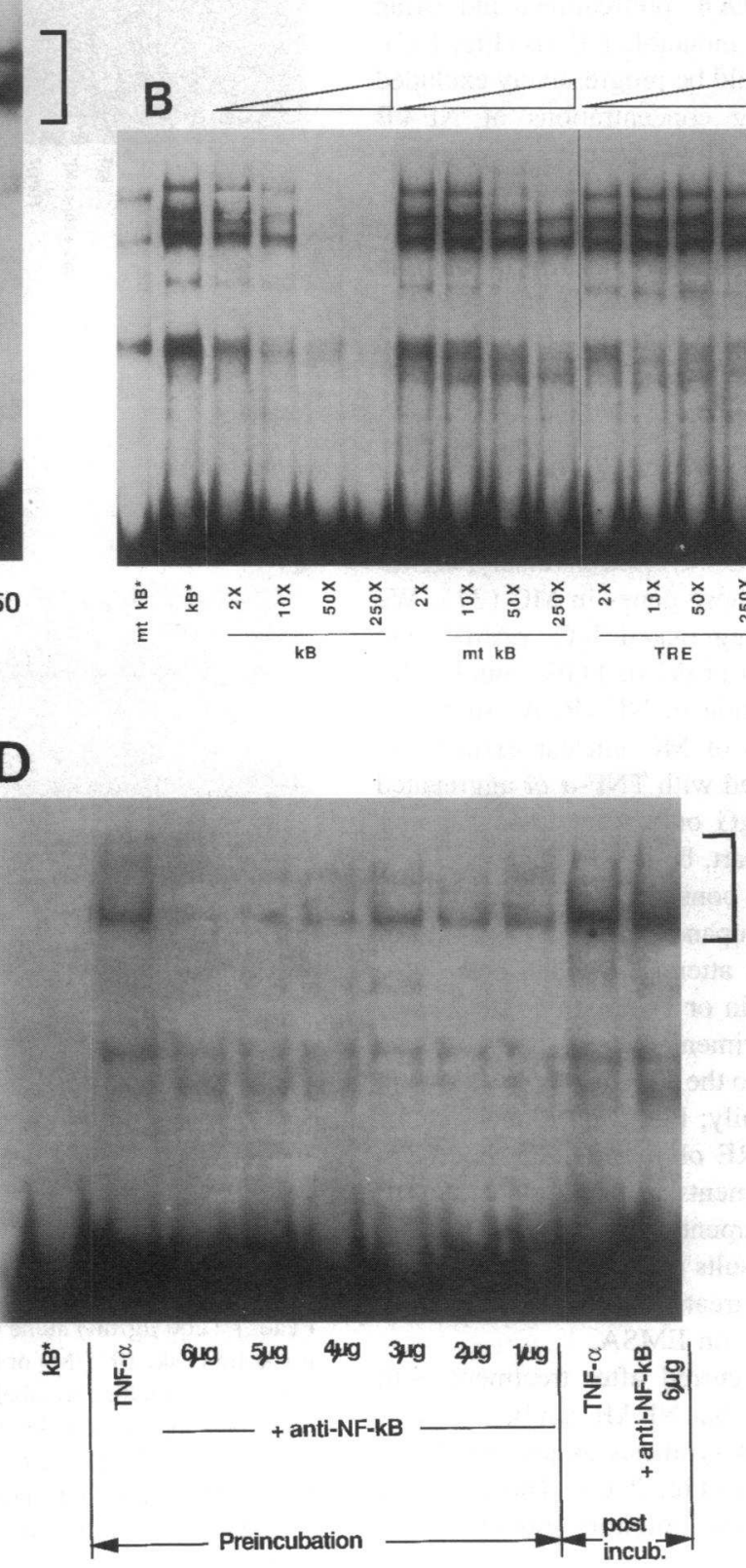

Figure 1. EMSA analysis for NF-kB activity in MC. $(A)$ Effects of increasing concentrations of Poly dI-dC as a nonspecific competitor on binding of labeled $\mathrm{kB}$ oligonucleotide sequence to nuclear extracts from MC preincubated with TNF- $\alpha(100 \mathrm{U} / \mathrm{ml})$. Brackets indicate position of NF-kB bands. $(B)$ Binding of nuclear extract from TNF- $\alpha$ stimulated $\mathrm{MC}$ to labeled mutant $\mathrm{kB}$ sequence (lane 1; see text) or to labeled control $\mathrm{kB}$ sequence (remaining lanes). Competition of binding was performed with increasing concentrations of unlabeled $\mathrm{kB}$ oligonucleotide, unlabeled kB-mutant oligonucleotide, or unlabeled TRE oligonucleotide. Concentration of Poly dI-dC was 50 $\mu \mathrm{g} / \mathrm{ml}$. (C) Binding of cytosolic fractions $(25 \mu \mathrm{g})$ of $\mathrm{MC}$ lysate to labeled $\mathrm{kB}$ oligonucleotide without (-) or with (+) DOC preincubation at room temperature for $10 \mathrm{~min}$ (results from a duplicate experiment). (D) Binding of nuclear extract from TNF- $\alpha$ stimulated MC ( $5 \mu \mathrm{g})$ without or with addition of monoclonal antibody against the p65 subunit of NF-kB (anti-NF-kB). Nuclear extracts were preincubated for $20 \mathrm{~min}$ at $37^{\circ} \mathrm{C}$ without (TNF- $\alpha$ alone) or with (TNF- $\alpha+$ anti-NF-kB) increasing concentrations of antibody prior to addition of labeled $\mathrm{kB}$ oligonucleotide to the binding reaction. Increasing concentrations of the antibody causes exclusion of the NF-kB bands. (Preincubation, lanes 2-8). When binding of nuclear extract and labeled $\mathrm{kB}$ sequence were performed prior to addition of antibody the NF-kB bands were not excluded (Post-incubation, lanes 9 and 10 ). shift assays (EMSA) using a 26-bp, end labeled oligonucleotide recognizing NF-kB of the immunoglobulin gene $(\mathrm{kB})$ as described by Zabel et al. (6). As shown in Fig. $1 A$, nuclear protein extracts from MC stimulated with TNF- $\alpha$ caused band retardation of the labeled $\mathrm{kB}$ DNA sequence. In preliminary experiments, using from 5 to $30 \mu \mathrm{g}$ of nuclear protein extracts, we established that optimal concentrations for the EMSA were present at 15-25 $\mu \mathrm{g}$ of nuclear extract. Increasing concentrations of poly $\mathrm{dI}-\mathrm{dC}$ as nonspecific competitor displaced multiple bands considered to be nonspecific. Poly dI-dC did not displace binding of bands with an NF-kB like motility even at $250 \mu \mathrm{g} /$ $\mathrm{ml}$ (Fig. $1 A$ ). There are several bands on the EMSA which most likely correspond to different NF-kB like factor subunit combinations. These NF-kB like bands could effectively be competed out with increasing concentrations of unlabeled NF$\mathrm{kB}$ binding DNA consensus sequence (Fig. $1 \mathrm{~B}$ ). In contrast, the mutated $\mathrm{kB}$ sequence was far less efficient $(\sim 20$-fold, as determined by densitometry) in binding nuclear proteins or in displacing labeled NF-kB binding DNA sequences indicating kB-specific DNA binding of the nuclear protein extracts. Fur- 
thermore, an oligonucleotide corresponding to the TPA regulatory element (TRE) recognition sequence was an ineffective competitor even at 250 -fold excess (Fig. $1 \mathrm{~B}$ ).

DOC has been shown to release the heterodimer NF-kB from IkB in vitro (41). EMSA on the cytosolic fraction of MC with or without pretreatment with DOC showed a marked increase in NF-kB binding after DOC pretreatment indicating that $\mathrm{MC}$ cytosol contains inactive, inducible NF-kB (Fig. $1 C$ ).

NF-kB-like factor binding could be progressively excluded by preincubating with increasing concentrations of NF-kB monoclonal antibody (Fig. $1 \mathrm{D}$ ). Thus the antibody prevents binding of the NF-kB to the $\mathrm{kB}$ sequence. Conversely no decrease in labeled $\mathrm{kB}$ oligonucleotide binding was observed when anti-NF-kB was added after the normal EMSA binding reaction. This would indicate that the epitope on the NF-kB is no longer accessible to the antibody once NF-kB is bound to the DNA element.

$T N F-\alpha$ or aggregated IgG activate $N F-k B$ in MC: effects attenuated by $c A M P$. Previously we have shown that exposure of MC to TNF- $\alpha$ or aggregated IgG results in increased expression of CSF-1 and MCP-1 with concurrent increases in the levels of their respective mRNA $(36,37)$. Conversely, cAMP downregulates the expression of these genes in MC (37). We therefore examined if TNF- $\alpha$, aggregated IgG, cAMP, and cAMP mimetics such as forskolin (Fsk) or $\mathrm{PGE}_{2}$ could influence the activation and translocation of NF-kB. As shown in Fig. $2 A$, NF-kB binding activity of MC nuclear extracts increased when cells had been treated with TNF- $\alpha$ or aggregated IgG. The $F\left(a b^{\prime}\right)_{2}$ fragment of IgG only resulted in a minor band-shift. This may, at least in part, be due to uncleaved IgG in the $\mathrm{F}\left(\mathrm{ab}^{\prime}\right)_{2}$ preparation. This is consistent with activation of NF-kB by Fc gamma receptor occupancy by IgG. The effect of TNF- $\alpha$ and aggregated IgG were attenuated when cells were preincubated with cAMP, forskolin or $\mathrm{PGE}_{2}$. In contrast, pretreatment of MC with these experimental agents had no effect on the binding of nuclear extracts to the TPA regulatory element (TRE, a member of the AP-1 family; Fig. $2 \mathrm{~B}$ ). Specificity of nuclear protein binding to the TRE oligonucleotide had been established in preliminary experiments using labeled mutated TRE oligonucleotide and displacement by unlabeled TRE and mutated TRE oligonucleotides (results not shown). This argues against a nonspecific effect of pretreatment of MC with TNF$\alpha, \mathrm{IgG}, \mathrm{cAMP}$, forskolin, or $\mathrm{PGE}_{2}$ on EMSA.

Activation of NF-kB also occurred after treatment with cycloheximide ( $\mathrm{CHX})$, indicating that NF-kB can be activated independent from de novo protein synthesis as previously reported by Sen and Baltimore (4) (Fig. $2 C$ ). The effect of cycloheximide has been related to the inhibitory subunit of NF$\mathrm{kB}(42)$.

In vitro treatment with protein kinase $A$ does not effect $N F$ $k B E M S A$. As cAMP decreased activation of NF-kB in response to TNF- $\alpha$, we examined whether this effect could be mimicked by PKA treatment of cell extracts. When nuclear or cytosolic extracts from MC pre-exposed to TNF- $\alpha$ were incubated with $\mathrm{MgCl}_{2}, \pm$ ATP or nonhydrolizable ATP gamma-S \pm catalytic subunit of PKA, no change in gel shift occurred (Fig. 3). Comparable results were obtained with extracts from cells that had not been exposed to TNF- $\alpha$ (results not shown). Similar results were obtained when ATP concentrations were raised to 1 and $10 \mathrm{mM}$ ATP (results not shown). Thus in vitro treatment with PKA did not induce activation of cytosolic NF-kB or
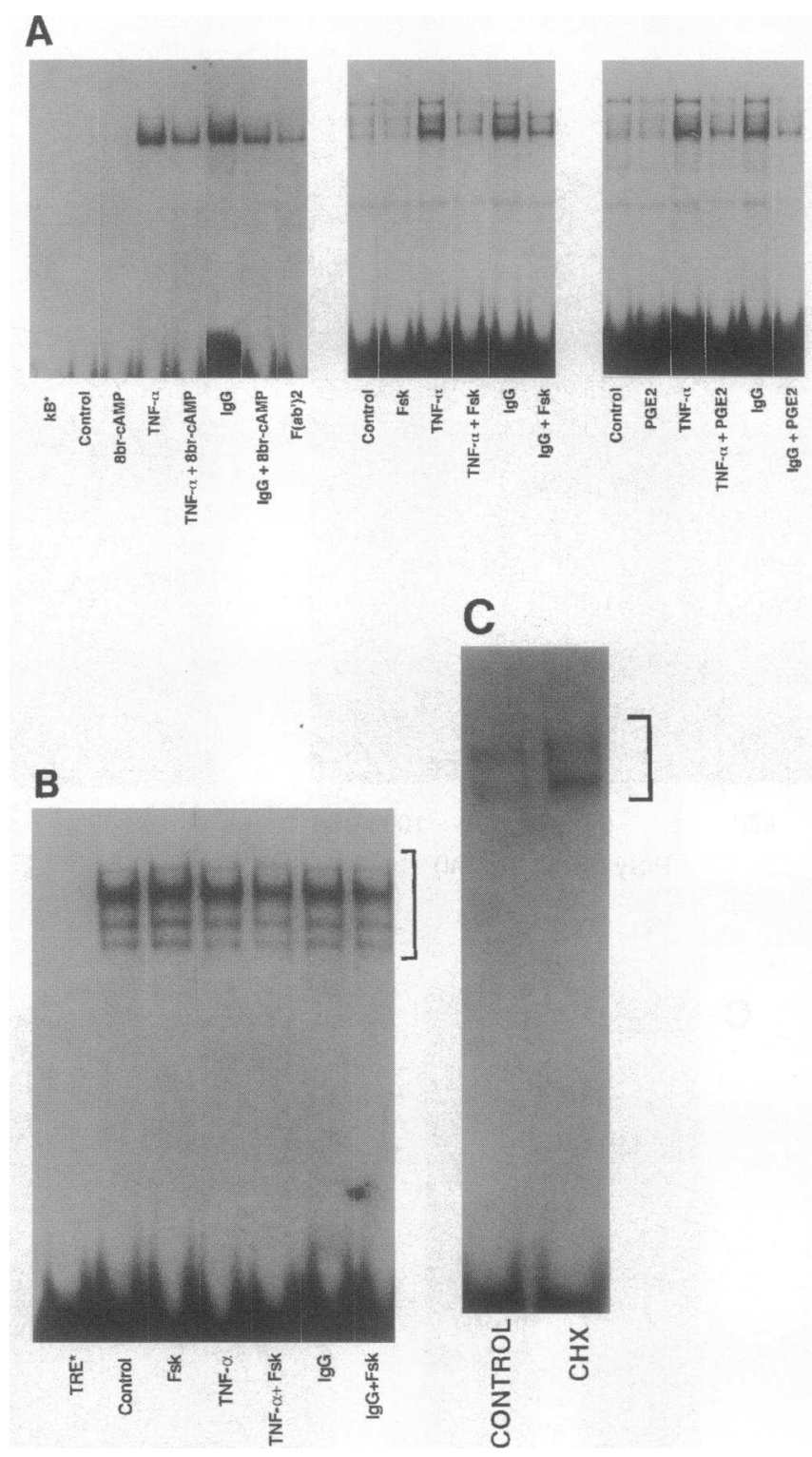

Figure 2. Effects of TNF- $\alpha(100 \mathrm{U} / \mathrm{ml})$, aggr. IgG $(200 \mu \mathrm{g} / \mathrm{ml})$ or $\mathrm{F}\left(\mathrm{ab}^{\prime}\right)_{2}(200 \mu \mathrm{g} / \mathrm{ml})$ alone or in combination with 8br-cAMP $(1 \mathrm{mM})$ forskolin (Fsk; $10^{-5} / \mathrm{M}$ ) or $\mathrm{PGE}_{2}\left(10^{-6} / \mathrm{M}\right)$ on EMSA for nuclear protein extracts binding to labeled kb oligonucleotide (Fig. $2 A$ ) or labeled TRE oligonucleotide (Fig. 2 B) . Cycloheximide (CHX; $15 \mu \mathrm{g} / \mu \mathrm{l}$ ) also activated NF-kB (Fig. $2 C$ ). MC were preincubated for $30 \mathrm{~min}$ with $8 \mathrm{br}-\mathrm{cAMP}$, Fsk or $\mathrm{PGE}_{2}$ prior to a 1-h co-incubation \pm TNF- $\alpha$ or aggregated IgG before extraction of nuclear proteins and EMSA. Comparable results were obtained in 5 sets of experiments for 8br-cAMP, 3 sets for forskolin and 4 sets for $\mathrm{PGE}_{2}$.

influence binding of the nuclear factor to the labeled $\mathrm{kB}$ oligonucleotide.

Generation of superoxide activates induction of $N F-k B$. It has been proposed that NF-kB can be activated by reactive oxygen intermediates and that activation can be suppressed by thiol containing radical scavengers such as NAC and PDTC (17-20). We recently provided evidence that reactive oxygen species may be involved in raising mRNA levels for MCP-1 and CSF-1 (38) consistent with the hypothesis that free radicals 


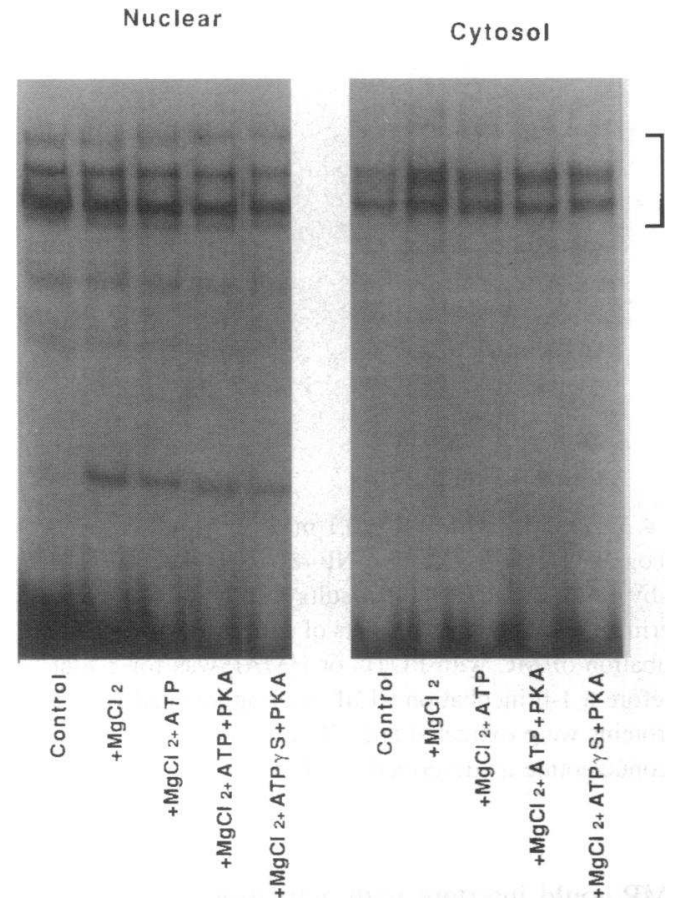

Figure 3. Effects of preincubation of nuclear or cytosolic extracts with protein kinase A. Cells were stimulated with TNF- $\alpha$ prior to extraction. $20 \mu \mathrm{g}$ nuclear protein or $50 \mu \mathrm{g}$ cytosolic extracts were preincubated with $\mathrm{MgCl}_{2}(1 \mathrm{mM}) \pm \mathrm{ATP}(100 \mu \mathrm{M})$ or ATP gamma-S (100 $\mu \mathrm{M}) \pm \mathrm{PKA}\left(0.2 \mu \mathrm{g}\right.$ catalytic subunit) for $10 \mathrm{~min}$ at $30^{\circ} \mathrm{C}$ prior to binding to labeled $\mathrm{kB}$ sequence and EMSA.

can serve as mediators in gene activation (43). We now examined if free radicals could also activate NF-kB in MC. As a thiol agent we used PDTC (20). Pretreatment of MC with PDTC partially but consistently inhibited the activation of NF$\mathrm{kB}$ in response to either TNF- $\alpha$ or aggregated IgG (Fig. 4 $A)$. These findings are consistent with free radicals serving as intermediates in NF-kB activation.

A membrane bound NADPH-dependent oxidase system has been implicated for the generation of oxygen free radicals in stimulated MC $(16,38)$. HMAP, also known as apocynin, a reported inhibitor of NADPH-dependent oxidase (44), can decrease superoxide generation by $\mathrm{MC}$ stimulated with either TNF- $\alpha$ or aggregated IgG and concurrently decrease expression of mRNA for CSF-1 and MCP-1 (38). We therefore used HMAP to see if this agent would also decrease activation of NF-kB by either TNF- $\alpha$ or aggregated IgG. Results with HMAP were similar to those with PDTC (Fig. $4 B$ ), i.e., HMAP attenuated the activation of NF-kB by TNF- $\alpha$ or IgG complexes. Again, EMSA using labeled TRE sequence were unaffected by TNF- $\alpha$ or aggregated IgG. In contrast to the attenuation of the NF-kB binding in the gel shifts after pretreatment in the presence of PDTC, PDTC enhances the EMSA for TRE (results not shown). Enhancement of AP-1 binding by PDTC has recently been described (45).

To examine whether generation of $\mathrm{O}_{2}^{-}$was also capable of activating NF-kB, we used generation of exogenous $\mathrm{O}_{2}^{-}$by the addition of xanthine oxidase and hypoxanthine (14) to the incubation media. Heat inactivated xanthine oxidase (by boiling the enzyme for $3 \mathrm{~min}$; iXO) served as control. As shown in Fig. 5 $A$, generation of $\mathrm{O}_{2}^{-}$activated NF-kB in MC, whereas treatment with heat inactivated XO had no effect. Furthermore the radical scavenger PDTC, as well as 8br-cAMP, also attenuated the activation of $\mathrm{NF}-\mathrm{kB}$ by $\mathrm{O}_{2}^{-}$. In contrast, $\mathrm{H}_{2} \mathrm{O}_{2}$ demonstrated no discernible effect on NF-kB in the EMSA (Fig. $5 B$ ). These results are in accord with our earlier studies where generation of $\mathrm{O}_{2}^{-}$, but not $\mathrm{H}_{2} \mathrm{O}_{2}$, stimulated mRNA levels of CSF-1 and MCP-1 (38).

\section{Discussion}

Our present results demonstrate a parallelism between the activation and attenuation of NF-kB activity in MC and our previous results for expression of mRNA for CSF-1 and MCP-1. Enhanced $\mathrm{kB}$ binding activity is produced in response to treatment with TNF- $\alpha$, aggregated IgG as well as by generation of $\mathrm{O}_{2}^{-}$by the xanthine oxidase-hypoxanthine system. This $\mathrm{kB}$ binding activity appears indistinguishable from native NF-kB in that: $(a)$ binding could be effectively competed out only with unlabeled NF-kB consensus sequence, but not with mutated $\mathrm{kB}$ sequence or the TRE consensus sequence (Fig. $1 B$ ); $(b)$ dissociation of cytosolic fractions of MC by DOC can release NF-kB from its cryptic form (Fig. 1 C), (41); (c) NF-kB-like binding activity can be induced in EMSA by pretreatment with CHX (Fig. $2 C$ ), (46); (d) $\mathrm{kB}$ binding activity is excluded when monoclonal antibodies to p65 subunits are added prior to the binding reaction (Fig. $1 \mathrm{D}$ ).

NF-kB has been implicated as a signal for cell distress in response to many adverse conditions, in which it can rapidly activate expression of inflammatory, immune, and acute phase response genes $(5,7)$. Two such genes that contain $\mathrm{kB}$ sequences upstream from their promoters and may fall under the regulation of NF-kB include the monocyte specific cytokines CSF-1 and MCP-1 $(21,22)$. MCP-1 and CSF-1 have been implicated in instituting and maintaining influx, proliferation, activation, and survival of monocyte-macrophages in immune-mediated diseases such as glomerulonephritis $(36-38,47)$. We recently demonstrated that transcription, as well as levels of mRNA and protein for CSF-1 and MCP- 1 are increased by TNF- $\alpha$ or aggregated IgG and attenuated by cAMP or cAMP mimetics such as forskolin or $\mathrm{PGE}_{2}$ (37). Our previous results thus correlate with the increased $\mathrm{kB}$ binding activity of MC stimulated by TNF- $\alpha$ or aggregated IgG and the diminished gel shift after cAMP pretreatment demonstrated in our present study (Fig. $2 \mathrm{~A}$ ).

In vitro highly purified NF-kB can be activated by phosphorylation, presumably at the IkB subunit, by cyclic AMP-dependent protein kinase (PKA) or protein kinase C (PKC) (9). Attempts were less successful with crude cytosolic extracts (9), with the exception of a study by Shirakawa and Mizel (48). Using 70Z/3 murine pre-B cells and a human natural killerlike cell line YT, these authors were able to demonstrate activation of NF-kB catalyzed by PKA or PKC phosphorylation. In our studies treatment of cytosolic or nuclear preparations with PKA neither activated nor inactivated NF-kB in MC (Fig. 3). Similar findings have been reported in the $\mathrm{T}$ cell lymphoma Jurkat cell line (10), or the monocyte cell line HL-60 (29). PKA, unlike PKC, was also unable to phosphorylate highly purified IkB in vitro (9). Surprisingly, pretreatment of cells 


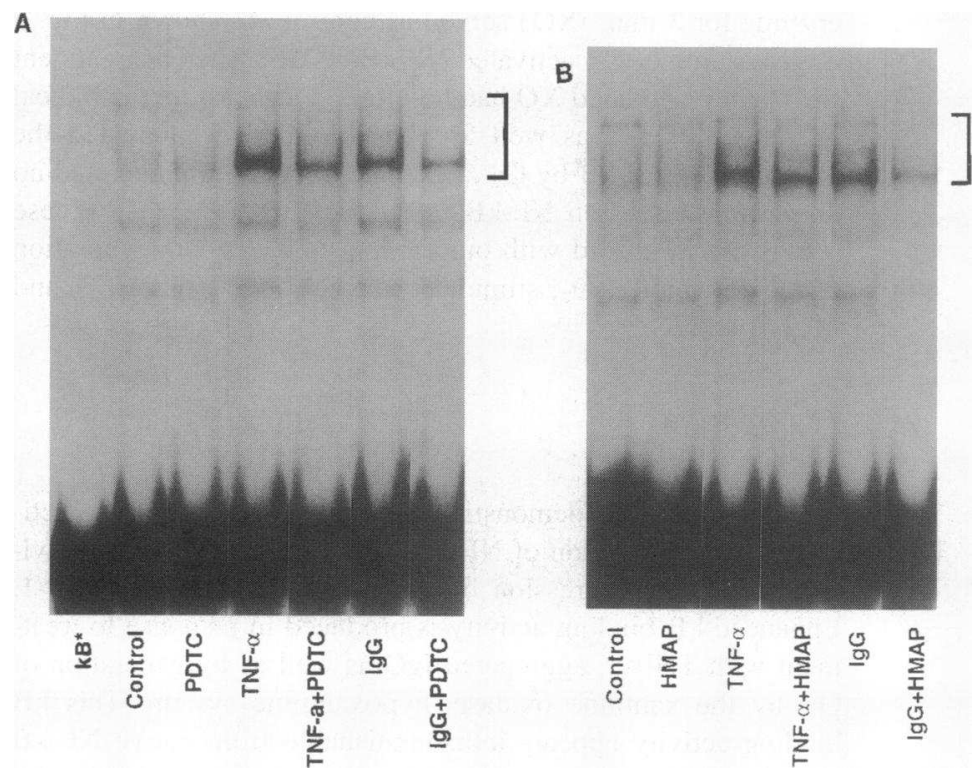

Figure 4. Effects of $(A)$ PDTC $(0.1 \mathrm{mM})$ or $(B)$ HMAP ( 100 $\mu \mathrm{g} / \mathrm{ml}$ ) on NF-kB activation by TNF- $\alpha$ or aggr. IgG as demonstrated by EMSA. Comparable results were obtained in 9 sets of experiments for PDTC and 4 sets of experiments for HMAP. Preincubation of MC with PDTC or HMAP was for $1 \mathrm{~h}$ at $37^{\circ} \mathrm{C}$ before a $1-\mathrm{h}$ incubation \pm TNF- $\alpha$ or aggregated IgG. Nuclear proteins were extracted and allowed to bind with labeled $\mathrm{kB}$ oligonucleotide as described in Methods. with cAMP or CAMP mimetics decreased the amount of nuclear NF-kB binding activity as determined by EMSA. This inhibitory effect of cAMP on nuclear NF-kB is apparent after stimulation of cells with TNF- $\alpha$, IgG complexes, or generation of superoxide anion. Thus in intact MC cAMP inhibits activation of NF-

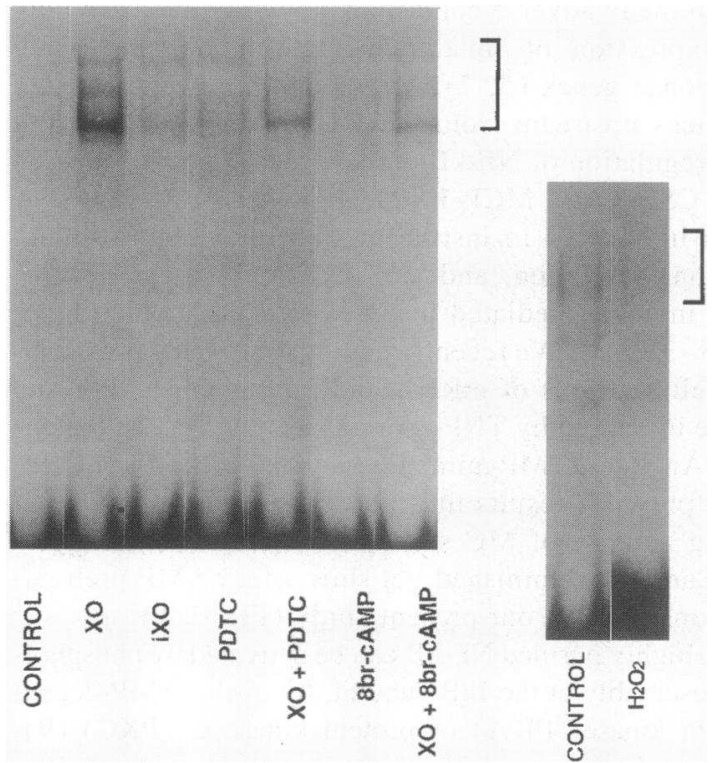

Figure 5. (A) Generation of superoxide anion by xanthine oxidase plus hypoxanthine (XO; $10 \mathrm{mU} / \mathrm{ml}$ and $0.5 \mathrm{mM}$, respectively) activates NF$\mathrm{kB}$. Heat inactivated xanthine oxidase (iXO) does not activate NF-kB. PDTC and cAMP inhibit activation of NF-kB in response to superoxide generation by xanthine oxidase (XO + PDTC and XO + 8br-cAMP). PDTC or 8br-cAMP by themselves had no effects. $\mathrm{H}_{2} \mathrm{O}_{2}(50 \mu \mathrm{M})$ does not activate NF-kB (Fig. $5 \mathrm{~B}$ ). Comparable results were obtained in three sets of experiments. MC were preincubated for $1 \mathrm{~h}$ with PDTC or for $30 \mathrm{~min}$ with $8 \mathrm{br}$-cAMP followed by a 1-h incubation $\pm \mathrm{XO}$ or $\mathrm{H}_{2} \mathrm{O}_{2}$. Nuclear proteins were extracted and bound to labeled $\mathrm{kB}$ as per Methods.
kB. Cyclic AMP could interfere with activation of NF-kB by TNF- $\alpha$ or IgG at multiple steps, e.g., (a) with signals leading to NF-kB activation; $(b)$ with NF-kB activation itself; $(c)$ with transfer of NF-kB to the nucleus; or $(d)$ with NF-kB binding to its DNA-recognition site. The fact that cAMP also decreased activation of NF-kB in response to superoxide anion would indicate that cAMP can interfere with steps downstream of $\mathrm{O}_{2}^{-}$generation. Our experiments using PKA catalytic subunit in broken cell preparations only indicate that in vitro treatment of cytosolic or nuclear fractions have no influence on NF-kB dissociation, or binding to the NF- $\mathrm{kB}$ specific oligonucleotide. Future experiments will have to examine the mechanism for the negative regulation of NF-kB by cAMP.

All agents examined induced the release of reactive oxygen intermediates (ROI). These intermediates have been implicated as second messengers in the induction of NF-kB (17-20). The ROI could be generated by NADPH oxidase, a membrane bound enzyme (49) found, in addition to phagocytic cell lines, in cells of mesenchymal origin, including MC $(16,38)$. This study shows that scavengers of ROI, such as PDTC, can attenuate activation of NF-kB in MC. HMAP, an inhibitor of ROI generation by NADPH-dependent oxidase $(38,44)$ also reduces activation of NF-kB, arguing in favor of ROI playing a role in NF$\mathrm{kB}$ activation. Generation of superoxide anion, but not $\mathrm{H}_{2} \mathrm{O}_{2}$, activates NF-kB providing an additional argument in favor of $\mathrm{ROI}$ as second messengers.

We find it intriguing to speculate on the correlation between regulation of mRNA levels for example, MCP-1 and CSF-1 in MC and activation of NF-kB. Thus cAMP decreases mRNA levels and EMSA for NF-kB in MC stimulated with TNF- $\alpha$ or IgG. Scavengers of free radicals or inhibition of their formation by HMAP also shows concordant effects on mRNA levels and NF-kB gel shifts. Generation of superoxide anion activates NF$\mathrm{kB}$ and increases mRNA levels for MCP-1 and CSF-1. While this correlation is highly intriguing it does not establish causality, which will require future experiments using reporter gene assays.

Overall our results support the proposed role for ROI in NF- 
$\mathrm{kB}$ activation and the resulting transcription of various genes including MCP-1 and CSF-1 involved in acute tissue injury. The attenuating effects of cAMP and radical scavengers on this process may indicate potential avenues for therapeutic interventions during glomerular injury, for example.

\section{Acknowledgments}

This work was supported by grant DK-22036 from the National Institutes of Health.

\section{References}

1. Schlondorff, D. 1987. The glomerular mesangial cell: an expanding role for a specialized pericyte. FASEB (Fed. Am. Soc. Exp. Biol.) J. 1:272-281.

2. McKnight, S., and R. Tjian. 1986. Transcriptional selectivity of viral genes in mammalian cells. Cell. 46:795-805.

3. Johnson, P. F., and S. L. McKnight. 1989. Eukaryotic transcriptional regulatory proteins. Annu. Rev. Biochem. 58:799-839.

4. Sen, R., and D. Baltimore. 1986. Multiple nuclear factors interact with immunoglobin enhancer sequences. Cell. 46:705-716.

5. Baeuerle, P. A., and D. Baltimore. 1991. The physiology of the NF-kB transcription factor. In The Hormonal Control Regulation of Gene Transcription. P. Cohen and J. G. Foulkes, editors. Elsevier Science Publishers, New York. 423 446.

6. Zabel, U., R. Schreck, and P. A. Baeuerle. 1991. DNA binding of purified transcription factor NF-kB: affinity, specificity, $\mathrm{Zn}^{2+}$ dependence, and differential half-site recognition. J. Biol. Chem. 266:252-260.

7. Baeuerle, P. A. 1991. The inducible transcription activator NF-kB: regulation by distinct protein subunits. Biochim. Biophys. Acta. 1072:63-80.

8. Leonardo, M. J., and D. Baltimore. 1989. NF-kB: A pleiotropic mediator of inducible and tissue-specific gene control. Cell. 58:227-229.

9. Ghosh, S., and D. Baltimore. 1990. Activation in vitro of NF-kB by phosphorylation of its inhibitor IkB. Nature (Lond.). 344:678-682.

10. Meichle, A., S. Schutze, G. Hensel, D. Brunsing, and M. Kronke. 1990. Protein kinase $\mathrm{C}$-independent activation of nuclear factor $\mathbf{k B}$ by tumor necrosis factor. J. Biol. Chem. 255:8339-8343.

11. Mathias, S., K. A. Dressler, and R. N. Kolesnick. 1991. Characterization of a ceramide-activated protein kinase: stimulation by tumor necrosis factor alpha. Proc. Natl. Acad. Sci. USA. 88:10009-10013.

12. Schutze, S., K. Potthoff, T. Machleidt, D. Berkovic, K. Wiegmann, and M. Kronke. 1992. TNF activates NF-kB by phosphatidylcholine-specific phospholipase C-induced "acidic" sphingomyelin breakdown. Cell. 71:765-776.

13. Dressler, K. A., S. Mathias, and R. N. Kolesnick. 1992. Tumor necrosis factor-alpha activates the sphingomyelin signal transduction pathway in a cellfree system. Science (Wash. DC). 255:1715-1718.

14. Radeke, H. H., B. Meier, N. Topley, J. Floge, G. G. Habermehl, and K. Resch. 1990. Interleukin 1-alpha and tumor necrosis factor-alpha induce oxygen radical production in mesangial cells. Kidney Int. 37:767-775.

15. Sedor, J. R., S. W. Carey, and S. N. Emancipator. 1987. Immune complexes bind to cultured rat glomerular mesangial cells to stimulate superoxide release: evidence for an Fc receptor. J. Immunol. 138:3751-3757.

16. Radeke, H. H., A. R. Crossi, J. T. Hancock, O. T. Jones, M. Nakamura, V. Kaever, and K. Resch. 1991. Functional expression of NAPDH oxidase components (alpha- and beta-subunits of cytochrome $b_{558}$ and 45-kDa flavoprotein) by intrinsic human glomerular mesangial cells. J. Biol. Chem. 266(31):2102521029.

17. Staal, F. J. T., M. Roederer, and L. A. Herzenberg. 1990. Intracellular thiols regulate activation of nuclear factor $\mathbf{k B}$ and transcription of human immunodeficiency virus. Proc. Natl. Acad. Sci. USA. 87:9943-9947.

18. Toledano, M. B. and W. J. Leonard. 1991. Modulation of transcription factor NF-kB binding activity by oxidation-reduction in vitro. Proc. Natl. Acad. Sci. USA. 88:4328-4332.

19. Schreck, R., P. Rieber, and P. A. Baeuerle. 1991. Reactive oxygen intermediates as apparently widely used messengers in the activation of the NF-B transcription factor and HIV-1. EMBO (Eur. Mol. Biol. Organ.) J. 10:2247-2258.

20. Schreck, R. and P. A. Baeuerle. 1991. A role for oxygen radicals as second messengers. Trends Cell Biol. 1:39-42.

21. Harrington, M. A., H. J. Edenberg, S. Saxman, L. M. Pedigo, R. Daub and H. E. Broxmeyer. 1991. Cloning and characterization of the murine promoter for the colony-stimulating factor-1-encoding gene. Gene (Amst.). 102:165-170.
22. Shyy, Y-J., Y-S. Li, and P. E. Kolattukudy. 1990. Structure of human monocyte chemotactic protein gene and its regulation by TPA. Biochem. Biophys. Res. Commun. 169:346-351.

23. Leonard, E. J. and T. Yoshimura. 1990. Human monocyte chemoattractant protein-1 (MCP-1). Immunol. Today. 12:97-101.

24. Oppenheim, J. J., C. O. C. Zachariae, N. Mukaida, and K. Matsushima 1991. Properties of the novel proinflammatory supergene "intercrine" cytokine family. Annu. Rev. Immunol. 9:617-648.

25. Yoshimura, T., N. Yuhki, S. K. Moore, E. Appella, M. I. Lerman, and E. J. Leonard. 1989. Human monocyte chemoattractant protein-1 (MCP-1). Fulllength cDNA cloning, expression in mitogen-stimulated blood mononuclear leukocytes, and sequence similarity to mouse competence. FEBS (Fed. Eur. Biochem. Soc.) Lett. 244:487-493.

26. Horiguchi, J., E. Sariban, and D. Kufe. 1988. Transcriptional and posttranscriptional regulation of CSF-1 gene expression in human monocytes. Mol. Cell. Biol. 8:3951-3954.

27. Introna, M., R. C. Bast, Jr., C. S. Tannenbaum, T. A. Hamilton, and D. O. Adams. 1987. The effect of LPS on expression of the early "competence" genes $\mathrm{JE}$ and $\mathrm{KC}$ in murine peritoneal macrophages. J. Immunol. 138:3891-3896.

28. Ernst, T. J., A. R. Ritchie, G. D. Demetri, and J. D. Griffin. 1989. Regulation of granulocyte- and monocyte-colony stimulating factor mRNA levels in human blood monocytes is mediated primarily at a post-transcriptional level. $J$. Biol. Chem. 254:5700-5703.

29. Sherman, M. L., B. L. Weber, R. Datta, and D. W. Kufe. 1990. Transcriptional and posttranscriptional regulation of macrophage-specific colony stimulating factor gene expression by tumor necrosis factor. Involvement of arachidonic acid metabolites. J. Clin. Invest. 85:442-447.

30. Strieter, R. M., R. Wiggins, S. H. Phan, B. L. Wharram, H. J. Showell D. G. Remick, S. W. Chensue, and S. L. Kunkel. 1989. Monocyte chemotactic protein gene expression by cytokine-treated human fibroblasts and endothelial cells. Biochem. Biophys. Res. Commun. 162:694-700.

31. Rollins, B. J., T. Yoshimura, E. J. Leonard, and J. S. Pober. 1990. Cytokine-activated human endothelial cells synthesize and secrete a monocyte chemoattractant, MCP-1/JE. Am. J. Pathol. 136:1229-1233.

32. Standiford, T. J., S. L. Kunkel, S. H. Phan, B. J. Rollins, and R. M. Strieter 1991. Alveolar macrophage-derived cytokines induce monocyte chemoattractant protein-1 expression from human pulmonary type II-like epithelial cells. J. Biol. Chem. 266:9912-9918.

33. Kawahara, R. S. and T. F. Deuel. 1989. Platelet-derived growth factorinducible gene JE is a member of a family of small inducible genes related to platelet factor 4. J. Biol. Chem. 264:679-682.

34. Rovin, B. H., T. Yoshiumura, and L. Tan. 1992. Cytokine-induced production of monocyte chemoattractant protein-1 by cultured human mesangial cells. J. Immunol. 148:2148-2153.

35. Zoja, C., J. Ming, S. Bettoni, M. Sironi, D. Renzi, F. Chiaffarino, H. E. Abboud, J. VanDamme, A. Mantovani, G. Remuzzi, and A. Rambaldi. 1991 Interleukin-1B and tumor necrosis factor-A induce gene expression and production of leukocyte chemotactic factors, colony-stimulating factors, and interleukin-6 in human mesangial cells. Am. J. Pathol. 138:991-1003.

36. Hora, K., J. A. Satriano, A. Santiago, T. Mori, E. R. Stanley, Z. Shan and D. Schlondorff. 1992. Receptors for IgG complexes activate synthesis of monocyte chemoattractant peptide 1 and colony-stimulating factor 1. Proc. Natl. Acad. Sci. USA. 89:1745-1749.

37. Satriano, J. A., K. Hora, Z. Shan, E. R. Stanley, T. Mori, and D. Schlondorff. 1993. Regulation of monocyte chemoattractant peptide (MCP-1) and macrophage colony stimulating factor (CSF-1) by interferon- $\tau$, tumor necrosis factora, IgG aggregates and cAMP in mouse mesangial cells (MC). J. Immunol. 150:1971-1978.

38. Satriano, J. A., M. Shuldiner, K. Hora, Y. Xing, Z. Shan, and D. Schlondorff. 1993. Oxygen radicals as second messengers for expression of the monocyte chemoattractant protein, JE/MCP-1, and the monocyte colony-stimulating factor, CSF-1, in response to tumor necrosis factor-alpha and immunoglobulin G. Evidence for involvement of reduced nicotinamide adenine dinucleotide phosphate (NADPH)-dependent oxidase. J. Clin. Invest. 92:1564-1571.

39. Wolf, G., U. Haberstroh, and E. G. Neilson. 1992. Angiotensin II stimulates the proliferation and biosynthesis of type I collagen in cultured murine mesangial cells. Am. J. Pathol. 140:95-107.

40. Schreiber, E., P. Matthias, M. M. Muller, and W. Schaffner. 1989. Rapid detection of octamer binding proteins with "mini-extracts", prepared from a small number of cells. Nucleic Acids Res. 17:6419.

41. Baeuerle, P. A., and D. Baltimore. 1988. Activation of DNA-binding activity in an apparently cytoplasmic precursor of the NF-kB transcription factor. Cell. 53:211-217.

42. Novak, U., B. G. Cocks, and J. A. Hamilton. 1991. A labile repressor acts through the NF-kB-like binding sites of the human urokinase gene. Nucleic Acids Res. 19:3389-3393.

43. Saran, M. and W. Bors. 1989. Oxygen radicals acting as chemical messengers: a hypothesis. Free Radical Research Communications. 7:213-220. 
44. Suzuki, Y., W. Wang, T. H. Vu, and T. A. Raffin. 1992. Effect of NADPH oxidase inhibition on endothelial cell Elam-1 mRNA expression. Biochem. Biophys. Res. Commun. 184(3):1339-1343.

45. Meyer, M., R. Schreck, and P. A. Baeuerle. 1993. $\mathrm{H}_{2} \mathrm{O}_{2}$ and antioxidants have opposite effects on activation of NF-kB and AP-1 in intact cells: AP-1 as secondary antioxidant-responsive factor. EMBO (Eur. Mol. Biol. Organ.) J. 12:2005-2015.

46. Liu, J., T. C. Chiles, R. Sen, and T. L. Rothstein. 1991. Inducible nuclear expression of NF-kB in primary B cells stimulated through the surface Ig receptor. J. Immunol. 146:1685-1691.
47. Bloom, R. D., S. Florquin, G. G. Singer, D. C. Brennan, and V. R. Kelley. 1993. Colony stimulating factor-1 in the induction of lupus nephritis. Kidney Int. 43:1000-1009.

48. Shirakawa, F. and S. B. Mizel. 1989. In vitro activation and nuclear translocation of NF-kB catalyzed by cyclic AMP-dependent protein kinase and protein. Mol. Cell. Biol. 9:2424-2430.

49. Krieger-Braver, H. I. and H. Kather. 1992. Human fat cells possess a plasma membrane-bound $\mathrm{H}_{2} \mathrm{O}_{2}$-generating system that is activated by insulin via a mechanism bypassing the receptor kinase. J. Clin. Invest. 89:10061013. 